\title{
Hybrid Fuzzy Based MPPT Techniques for Maximum Power Extraction
}

\author{
K.Soujanya, J.Upender, Sai Srinivas, J.Vijaya Laxmi
}

\begin{abstract}
The extensive usage of solar has extended the opportunity of research to increase the efficiency of $P V$ module. Maximum Power Point Tracking technique plays an important role. In $P \& O$ and Incremental conductance the power produced is less. In this paper a Fuzzy based $P \& O$ and Fuzzy based Incremental Conductance MPPT techniques are presented to extract the maximum power from the photovoltaic system by considering the dynamic variation in irradiations and temperature also. Here the $100 \mathrm{~kW} \mathrm{PV}$ array is considered and it is connected to the utility grid via a DC-DC boost converter of 500volts with a 3 phase three level voltage source converter. The result is obtained by the MAT LAB Simulink and the same is appraised with the traditional $P \& O$ and Incremental conductance. The PV System produces the maximum power by the application of Fuzzy based incremental Technique compared to conventional methods.
\end{abstract}

Key Words: Maximum Power Point, Perturb \& Observe, Incremental conductance, Hybrid Fuzzy Logic

\section{INTRODUCTION}

In India, one of the most prime concerns in power sector is the greater demand for power which, by utilizing the conventional sources of energy is not sufficient to supply available power and to encounter increased demand.

Generation of the power is improved by the RE (Renewable energy) sources that use standard networks to meet day to day demand. Prime sources of renewable energy, wind and solar are mostly used in the power sector now a days.

The solar energy is more accessible because it is possible to extract maximum power [1]. The solar PV may be either a grid connected unit or standalone generating unit mostly to be controlled by accessibility of the nearby power grid.

In view of the present energy crisis and extermination of non-renewable source it is necessary a generate power by alternate means. Renewable energy like Solar and wind are widely used now-a-days efficiently. Development of the material science and power electronics greatly minimized the conversion of power processes in past few years and also helps in the development of lossless systems which are powerful and it can withstand the day to day demand of power.

Sumedha Sengaret.al [1] in this paper presented a review of different MPPT techniques like P \& O,hill climbing,

Revised Version Manuscript Received on August 19, 2019.

K.Soujanya, Associate Professor, CMR College of Engineering \& Technology, Ph.D Research Scholar, Osmania University, Hyderabad, Telengana, India.

Dr.J.Upender, Assistant professor, Osmania University, Hyderabad, Telengana, India.

Sai Srinivas, PG Scholar, Osmania University, Hyderabad, Telengana, India.

Smt.J.Vijaya Laxmi, Ph.D Research Scholar (Bio-technology), Osmania University, Hyderabad, Telengana, India.
Incremental Conductance, Curve Fitting method, Differential Method etc and detailed $\mathrm{dP} / \mathrm{dV}$ calculation of $\mathrm{P} \& \mathrm{O}$ and $\Delta \mathrm{I} / \Delta \mathrm{P}$ calculation for, Incremental Conductance are presented.

Raghuram Munasala et.al [2] proposed fuzzy logic based controller for maximum power point tracking. It is important to track the Maximum power in solar PV systems to enhance the output conditions and improve PV efficiency. Modelling of Photo Voltaic system is presented in this paper for different irradiances and temperatures. The efficiency of Fuzzy based Maximum Power Point Tracking (MPPT) method is compared with Incremental Conductance MPPT method.

Bhasuthkar Niharika et.al [3] in this paper presented a DC-DC converter with PV system with high efficiency for mini Unmanned Air Vehicle (mUAV). The tracking of maximum power is achieved by matching the impedance through the variation of duty cycle and efficiency is calculated with and without MPPT module.PV cell based renewable energy ismore efficient with MPPT module as compared towithout MPPT module.

Nada Zinelaabidine, Mohammed Karim et.al [4] presented the study and simulation of different maximum power point (MPPT) algorithms to increase the efficiency of photovoltaic (PV) connections and the results from this study specify that: In view of the available accuracy, the MPPT efficiencies of the $\mathrm{P} \& \mathrm{O}$ and FLC algorithms are in actual fact the same. But the INC algorithm is to some extent better. Related to performance, the FLC algorithm is better with low oscillation, which adds to a high stability of operation.

Carlos Robles Algarín et.al [5] in his paper presented an MPPT based on Fuzzy Logic for a PV System in which P\&O controller and fuzzy logic controller is simulated and results are compared. The simulation results validated less settling time, power loss and oscillations at the operating point for afuzzy controller.

Abdullah M. Noman et.al [6] in his paper presented an intelligent Fuzzy based MPPT for varying temperature and irradiation. Fuzzy based results are compared with P \& O which proved that the fuzzy based MPPT tracked maximum power accurately and successfully under all conditions giving maximum efficiency and better performance

Hasan Mahamudul, et.al [7] simulated a modelling technique of PV module with a fuzzy logic based MPPT algorithm and boost converter. In this paper a precise duty cycle control with respect to different atmospheric are 
applied for various PV modules and the results are validated by comparing with theoretical prediction

Kashif Ishaqueet.al [8] in his paper assessed the performance of perturb and observe $(\mathrm{P} \& \mathrm{O})$ and incremental conductance (IC) MPPT technique on the basis of European Efficiency Test, EN 50530 for the dynamic conditions of PV system. Both the methods producednearlycomparable dynamic MPPT efficiency.

M.A.A.Mohd Zainuri et.al [9] in this paper proposed an adaptive perturb and observe (P\&O)-fuzzy control maximum power point tracking (MPPT) for photovoltaic (PV) boost dc-dc converter. It is a combination of $\mathrm{P} \& \mathrm{O}$ and fuzzy logic technique which considers the advantages both the methods. Performance assessments like overshoot, time response, oscillation and stability as described are discussed in the paper.

Chandani Sharma, et.al [10] developed an efficient PV MPPT system using hybrid fuzzy technique to extract maximum power under multivariable environment (changing temperature and irradiance). This system optimizes the MPPT working performance when compared with previously used single variable approach achieved for buck converter and is monitored precisely using hybrid fuzzy controller (PD+I FLC). In the traditional MPPT algorithms like P \& O and Increment Conductance has the drawback that the MPP oscillates around the operating point. Thispaper presents a hybrid fuzzy based P \& O and Incremental Conductance to obtain the maximum power from the photo voltaic system.

\section{PHOTO VOLTAIC CELL}

The Photo Electric or Photo Voltaic Cell uses photo electric effect to transform light energy to the electrical form of energy. Electron is released when energy of photon is exceeded than energy of bandgap and current is generated by the flow of electrons

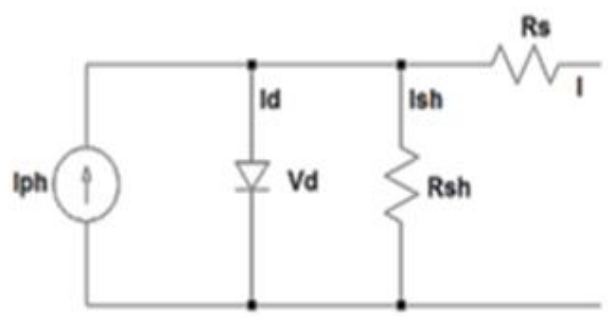

\section{Figure 1: Diode model of photo electric cell}

\section{A.Modelling of Photo Voltaic Cell}

Several photovoltaic cells are present in PV array which are connected in combinations of parallel \& series. S.Muthubalaji et.al [22] discussed the enhanced single diode model for various weather conditions Parallel connection is mainly organized for increase the current in array \& series connection of cells is mainly for improving the voltage of module. Current source is used \& parallel connected inverted diode is modelled as solar cell. Solar cell has its own parallel (Rsh) \& series resistance ( $\mathrm{R}$ s). In this model the shunt resistance (Rsh) is greater \& it is neglected.

Output current of Photo voltaic array shown below as:

$$
\begin{aligned}
& \mathrm{I}=\mathrm{Isc}-\mathrm{I}_{\mathrm{D}} \\
& I_{D}=\text { Io }\left(e^{\wedge}\left(q V_{D} / k T\right)-1\right) \\
& \text { Where } V_{D} \text { - Voltage across diode } \\
& \text { K - Boltzmann constant } \\
& \mathrm{T} \text { - Temperature at junction in } \\
& \text { Q - Electron charge \& } \\
& \text { Io - Reverse saturation current of } \\
& \text { diode } \\
& I=I s c-\left(I o\left(e^{\wedge}\left(q V_{D} / K T\right)-1\right)\right) \\
& \text { Using approximations, } \\
& \mathrm{I}=\mathrm{Isc}-\mathrm{Io}(\mathrm{eq}((\mathrm{V}+\mathrm{IRs}) / \mathrm{nkT})-1)
\end{aligned}
$$

Here V is PV cell voltage, I is PV cell current, $\mathrm{n}$ is diode ideality factor \& $\mathrm{T}$ is temperature in Kelvin.

\section{MPPT ALGORITHMS}

The percentage of the incident solar irradiance which is converted to electrical form by the PV panel is very less and the efficiency of the PV panel can be improved by using the

\begin{tabular}{|c|c|c|}
\hline $\begin{array}{l}\text { Serial } \\
\text { no. }\end{array}$ & Parameter & $\begin{array}{c}\text { Value taken } \\
\text { for } \\
\text { Simulation }\end{array}$ \\
\hline 1. & Irradiance & $1000 \mathrm{~W} / \mathrm{m}^{2}$ \\
\hline 2. & Temperature & $25^{\circ} \mathrm{Celsius}$ \\
\hline 3. & Switching Frequency & $5000 \mathrm{HZ}$ \\
\hline 4. & $\begin{array}{l}\text { Temperature } \\
\text { coefficient of (Voc) }\end{array}$ & $\begin{array}{l}-0.27258 \\
\% / \text { deg.C }\end{array}$ \\
\hline 5. & $\begin{array}{l}\text { Temperature } \\
\text { Coefficient of (Isc) }\end{array}$ & $\begin{array}{l}0.061749 \\
\% / \text { deg.C }\end{array}$ \\
\hline 6. & $\begin{array}{l}\text { No. of parallel strings } \\
\text { of an array }\end{array}$ & 66 \\
\hline 7. & $\begin{array}{l}\text { No. of series } \\
\text { connected modules for } \\
\text { each string }\end{array}$ & 5 \\
\hline 8. & $\begin{array}{l}\text { Open circuit voltage } \\
\left(V_{O C}\right)\end{array}$ & 64.1 volts \\
\hline 9. & $\begin{array}{l}\text { Short-Circuit Current } \\
\left(\mathrm{I}_{\mathrm{SC}}\right)\end{array}$ & 5.95 amps \\
\hline 10. & $\begin{array}{l}\text { Maximum power of } \\
\text { Module }\end{array}$ & $305.226 \mathrm{~W}$ \\
\hline 11. & $\begin{array}{l}\text { Light-generated } \\
\text { current } I_{\mathrm{I}} \text { (A) }\end{array}$ & 6.0092 amps \\
\hline
\end{tabular}
MPPT (Maximum Power Point Tracking technique). Impedance matching problem improves the maximum power tracking.By using MPPT and by varying D (Duty Cycle) of the Boost Converter at source side, source impedance is matched to load impedance appropriately where the maximum point is reached.

Few of the most popular MPPT algorithms are Incremental Conductance Method, Perturb and Observe MethodFractional Voc method, Fractional

Table I: PV panel specifications and parameters used in this Simulation 
Isc method, FLC method [2][3] [4]\&[5] and Neural Networks.

\section{HYBRID FUZZY LOGIC BASED P \& O METHOD}

In Hybrid FLC based MPPT technique,variations of voltage and variations in maximum power of $\mathrm{PV}$ cell will be given (FLC method) as input. Table 2 represents combinations of data base fuzzy rules with FLC based variables as input.

The FLC based rules are designed based on the Fuzzy factors [6]. Five variables named as zero, positive big, positive small, negative big \& negative small are described as linguistic input variables. The output current and voltage of the PV cell will be changed by the output from the FLC duty ratio (D) command of boost topology. The next set of the fuzzy linguistic input variables are mainly affected by the output of the PV cell. Accordingly the re-adjustment of the output commands are done by FLC based method.

The basic concept of this algorithm is explained by perturb \& observe (P \& O) technique. The FLC based database and rules are divided as nine regions depending upon features of $\mathrm{PV}$ cell as shown in figure 2

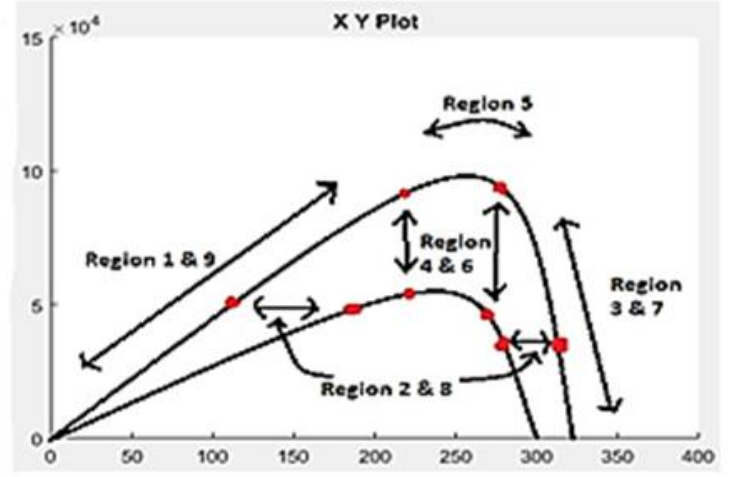

\section{Figure 2. PV curve of Fuzzy Logic P\&O Method}

The fuzzy logic based P \& O method algorithm for various regions shown in Table 1and figure 2 are detailed.

\section{Region 1:}

In this region the voltage \& power reduces, location of operating point is near to left of MPP (Maximum Power Point). Variations of voltage and variations of power are used to reduce the duty ratio so that it will reach MPP.

\section{Region 2:}

In this region, the voltage is reduced and power remains constant. For this situation, operating point is assumed to be near to the maximum power point and it is not possible to decide whether the operating point is right or left side of MPP, when the irradiance is changing hence $\mathrm{ZE}$ is maintained as output.

\section{Region 3:}

In this region the voltage is decreases and power is increased. The MPP is situated left to the operating point. For these the duty ratio needs to be increased

Region 4:
In this method the power is decreased and voltage is maintained as constant. In these situations, if the irradiance and temperature may or may not vary, it is unable to determine whether MPP is situated at right or left. So in this region $\mathrm{ZE}$ is maintained as output.

\section{Region 5:}

When both changes in voltage and changes in power are not varied in the system it means that it will track \& arrives at MPP. In region 5 the duty cycle (D) maintained unchanged and $\mathrm{ZE}$ will be maintained as output.

\section{Region 6:}

In the 6th region, voltage is maintained as constant and the power is increasing. Here the system is not able to find whether MPP (maximum power point) is situated at right or left. So that the ZE (zero) would be set as output of region 6 .

Whenever irradiance and temperature varies, still algorithm cannot detect if operating point is situated at left or right side of Maximum Power Point. In order to prevent the contradictions ZE is maintained as output.

\section{Region 7:}

In this region the voltage increases and power is decreases. The MPP (Maximum power point) is situated left to the operating point. For these conditions the changes in voltage $\&$ changes in power will be utilized to increment the duty ratio

\section{Region 8:}

In this region the voltage has improved and power remains as constant. For this situation, operating point is assumed that, it will be near to maximum power point, hence maintaining the ZE as output. MPP is achieved when the irradiance and temperature is unchanged. In this method it is not able to decide if irradiance is decreased or increased, so it maintains ZE as output.

\section{Region 9:}

In this region the voltage $\&$ power increases, location of operating point near left of MPP (Maximum Power Point). Variations of voltage and power are used to reduce the duty ratio. Voltage \& power are utilized to find the magnitude and to diminish the $\mathrm{D}$ (mitigates the duty cycle). Shifting to the later point, voltage $\&$ power both will be improved. At this stage MPP (Maximum power point) is situated left to the operating point hence it shows that $\mathrm{D}$ (duty ratio) would be improved for finding MPP as this will lead to system fluctuations, changes of duty ratio cannot be too high.

\section{HYBRID FUZZY LOGIC BASED INC METHOD}

This FLC based MPPT algorithm method uses gradient of photo voltaic cell $\mathrm{P}-\mathrm{V}$ (power-voltage) curve $\mathrm{S}(\mathrm{k})$ \& variation of the slope $(\Delta \mathrm{S}(\mathrm{k}))$ as FLC input variables is shown in table 3. 
Table 3: Fuzzy Rules for Fuzzy Logic Based IC Method

\begin{tabular}{|c|c|c|c|c|c|c|}
\hline \multirow{2}{*}{\multicolumn{2}{|c|}{ FUZZY RULE }} & \multicolumn{5}{|c|}{$S(k)$} \\
\hline & & NB & NS & $2 \mathbf{E}$ & PS & PB \\
\hline \multirow{5}{*}{$\Delta \mathbf{S}(\mathrm{K})$} & NB & ZE & PB & PS & ZE & $\mathrm{NB}_{1}$ \\
\hline & NS & TPB & PS & $2 \mathbf{E}$ & $\overline{2 E}$ & NB \\
\hline & ZE & PB & PS & $2 \mathbf{E}$ & NS & NB \\
\hline & PS & PB & ZEE & ZE & NS & NB \\
\hline & PB & PB & 2E & NS & NB & $2 E^{\prime}$ \\
\hline
\end{tabular}

According to above table, the three regions are shown from fuzzy rule database and the detailed explanation is provided by the observation for Fuzzy logic based rules and database of every region.

\section{Region 1:}

In this region, the MPP is situated at left of the operating point, slope of this region is negative. To achieve $\&$ track the MPP (maximum power point) the Dutyratio (D) should be intensified. The duty ratio (D) magnitude is to be improved by the second set of input variables.

The operating point is near to the MPP so that both $\Delta \mathrm{V} \&$ $\Delta \mathrm{P}$ are very minimum values; $\mathrm{ZE}$ will be set as FLC output in order to avoid the output becoming

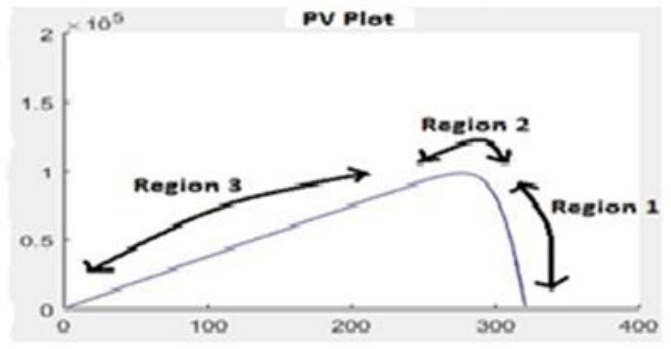

\section{Figure 3. PV curve of Fuzzy Logic Based IC Method}

NB \& generating the output error after the division. The MPP is situated at left of operating point $\&$ it is moving from MPP (maximum power point) to the right side further when the slope is NS and changes of slope is either negative or zero.

\section{Region 2:}

In this region, slope is $\mathrm{ZE}$ and change of slope is changing that the operating point located near to MPP (maximum power point) PV curve of Fuzzy Logic Based IC Method. Hence, in this technique the duty ratio is maintained as same under these circumstances. If changes of slope is NB, then the operating point will be expeditiously tracking the MPP from the left side (duty ratio diminished). When changes of slope is PB, MPP (maximum power point) is located left to the operating point. Sudden intensifying of the duty ratio will cause the operating point moving from MPP to left side of maximum power point, FLC would use NS as output to minimize the magnitude of changes of Dutyratio $(\Delta D)$.

\section{Region 3:}

In this region, slope is positive \& MPP is located right of the operating point as shown in fig 3.The duty ratio is decreased for MPPT under these conditions. The extent of duty ratio diminished and regulated by the second set of input variables. In this region both slope \& changes of slope is PB, FLC (Fuzzy Logic Controller) may generates incorrect outputs, receivable to the reasons similar to that Region no.1. ZE will be setting as FLC output in order to avoid such conditions.

\section{MATLAB/SIMULATIONRESULTS}

In this simulation model of MPPT system, 100KW PV array is connected to the utility grid via a DC-DC boost converter of 500volts and a 3 phase three level voltage source converter. MPPT is implemented in the boost converter by using Matlab code for three algorithms viz P \& O technique, Incremental conductance and Hybrid Fuzzy Logic based Algorithm with PWM generator.

Parameters of $\mathrm{P} \& \mathrm{O}$ algorithm are shown as; initial value of boost converter duty cycle is given as 0.5. Upper and Lower limits of the $\mathrm{P} \& \mathrm{O}$ algorithm are 0.8 and 0.1 respectively, which are shown in figure 4

\section{Parameters for Perturb and Observe Apoirtm: \\ $(0=800 s t$ convarar otyogde)}

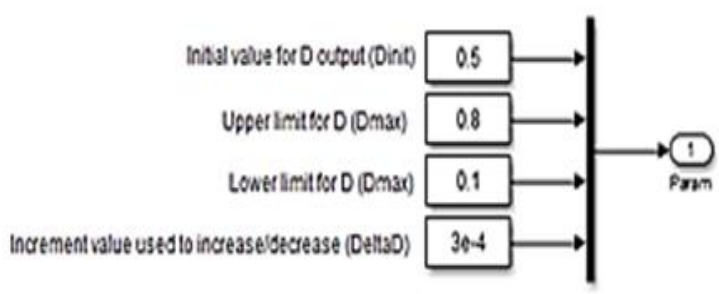

\section{Figure 4.Input to MPPT parameters Controller}

The variation of irradiation and temperature are shown in figures 5 and 6 respectively

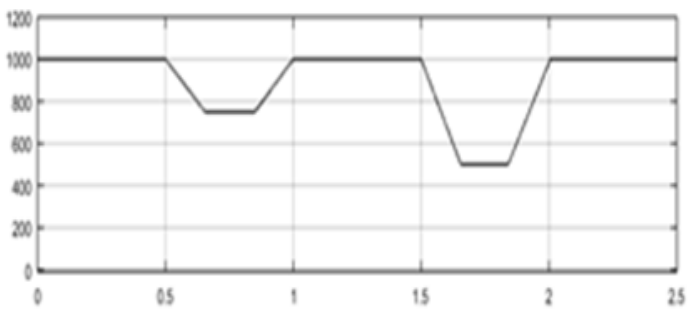

\section{Figure 5: Variation of irradiation curve with time in $\mathrm{sec}$}

and are considered the same for all MPPT algorithms methods

The irradiation curve has following stages:

- From (0 to 0.5$),(1$ to 1.5$)$ and (2 to 2.5$)$ the irradiation is $1000 \mathrm{w} / \mathrm{sq}-\mathrm{m}$.

- From (0.5 to 0.65$)$, (1.5 to 1.65$)$ the irradiation is decreasing.

- From (0.86 to 1$),(1.86$ to 2$)$ the irradiation is increasing.

- From (0.66 to 0.85$)$ and (1.66 to 1.85$)$ the irradiation is $750 \mathrm{w} / \mathrm{sq}-\mathrm{m}$ and $500 \mathrm{w} / \mathrm{sq}-\mathrm{m}$ respectively

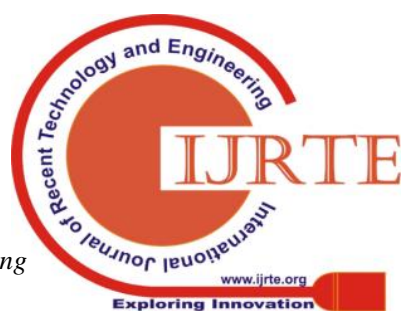




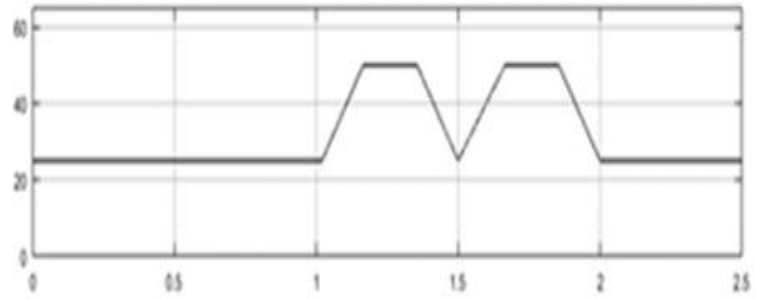

Figure 6: Variation of temperature curve with time in all MPPT methods

The temperature curve has following stages:

- From (0 to 1) and (2 to 2.5) the temperature is $25^{\circ}$.

- From (1 to 1.16$)$, (1.5 to 1.66$)$ the temperature is increasing.

- From (1.36 to 1.5$)$, (1.86 to 2$)$ the temperature is decreasing.

- From (1.17 to 1.35$)$ and (1.67 to 1.85$)$ the temperature is $50^{0}$

\section{COMPARISON ANALYSIS OF MPPT METHODS \& RESULTS}

Comparison of Power characteristics is divided in to eleven stages which are shown bin figure 7
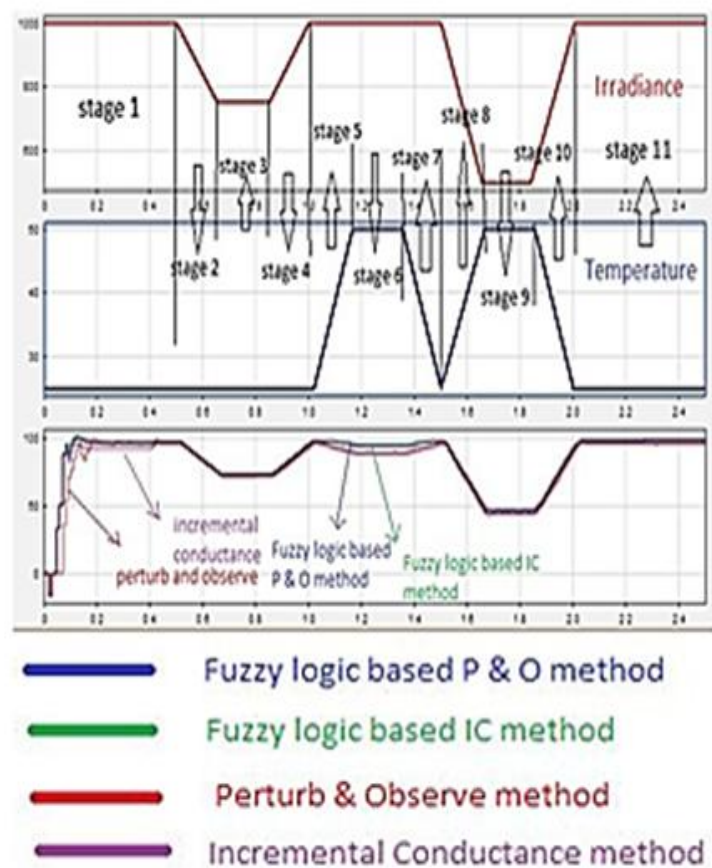

Figure 7: Power characteristics comparison of grid Photo Voltaic system showing various MPPT algorithms vs time

Stage 1:

From ( 0 to 0.5$)$ the irradiation is maintained constant at $1000 \mathrm{w} / \mathrm{m} 2$ and the temperature is $25^{\circ}$ Celsius. The variation of power starts from 0 and reaches the maximum point due to variation of temperature and irradiance.

FLC based IC method has more power when compared to other mppt methods

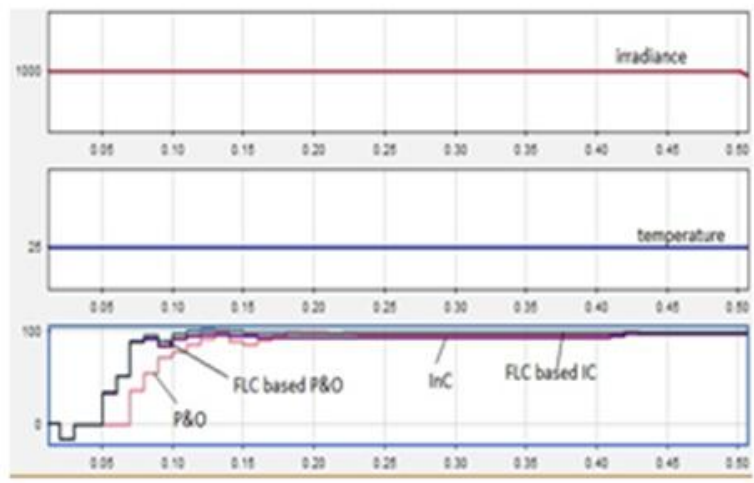

Figure 8: Power Characteristics in stage 1

Stage 2:

From (0.5 to 0.65$)$ the irradiation is decreases from $1000 \mathrm{w} / \mathrm{m} 2$ to $750 \mathrm{w} / \mathrm{m} 2$ and the temperature is $25^{\circ}$ Celsius. The variation of power is decreases due to variation of irradiance.

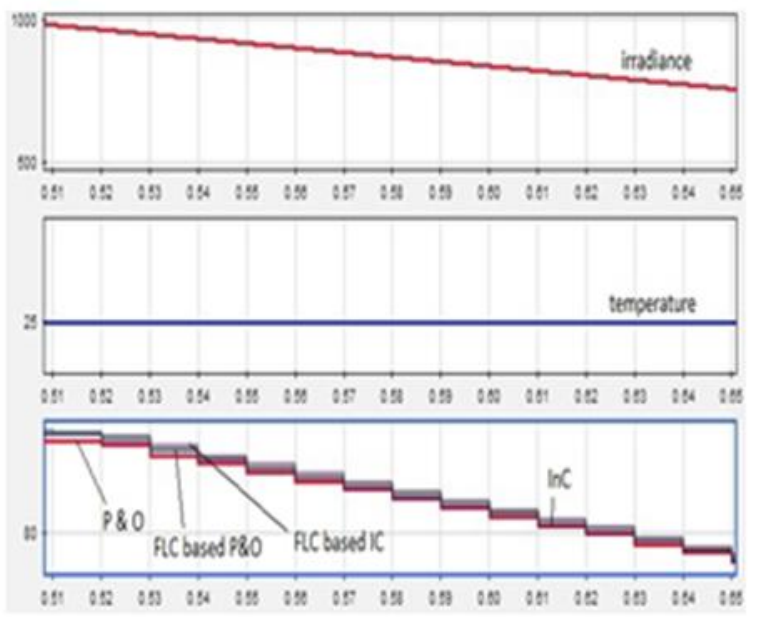

Figure 9: Power Characteristics in stage 2

FLC based $\mathrm{P} \& \mathrm{O}$ has less power when compared to FLC based IC method. P \& O method has less power when compared allmethods.

Stage 3:

From (0.66 to 0.85$)$ the irradiation is maintained constant $750 \mathrm{w} / \mathrm{m} 2$ and the temperature is $25^{\circ}$ Celsius. The variation of power is constant due to variation of irradiance and temperature are constant. 


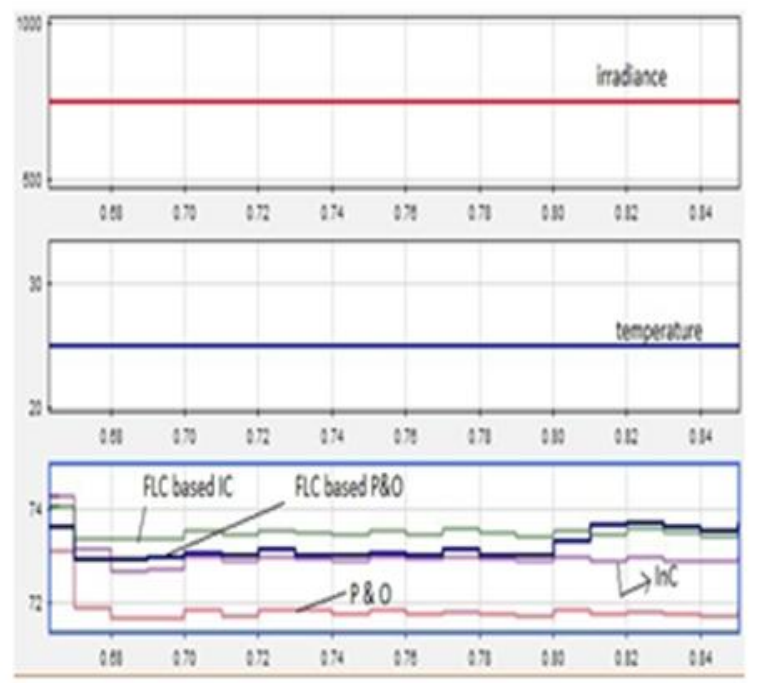

Figure 10: Power Characteristics in stage 3

Incremental method has more power when compared to $\mathrm{P}$ $\& \mathrm{O}$ but has less power when compared FLC methods

\section{Stage 4:}

From ( 0.86 to 1$)$ the irradiation is increases from $750 \mathrm{w} / \mathrm{m} 2$ to $1000 \mathrm{w} / \mathrm{m} 2$ and the temperature is $25^{\circ}$ Celsius. The variation of power is increases due to variation of irradiance.

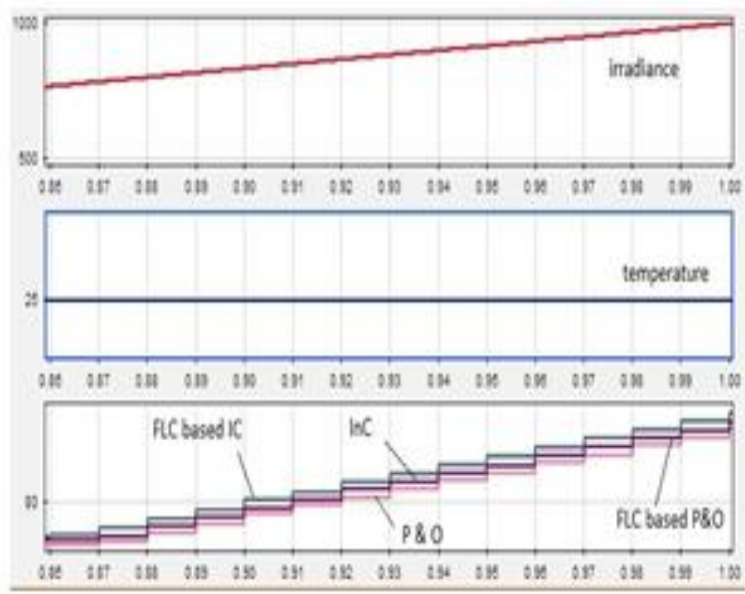

\section{Figure 11: Power Characteristics in stage 4}

FLC based IC has more power when compared to FLC based P\&O. P \& O method has less power when compared to all methods.

\section{Stage 5:}

From (1 to 1.16) the temperature is increases from $25^{\circ} \mathrm{Celsius}$ to $50^{\circ} \mathrm{Celsius}$ and the irradiance is $1000 \mathrm{w} / \mathrm{m} 2$. The variation of power is decreases due to variation of temperature.It shows that $\mathrm{P} \& \mathrm{O}$ method has less power when compared IC method. FLC based IC has more power when compared to all methods.

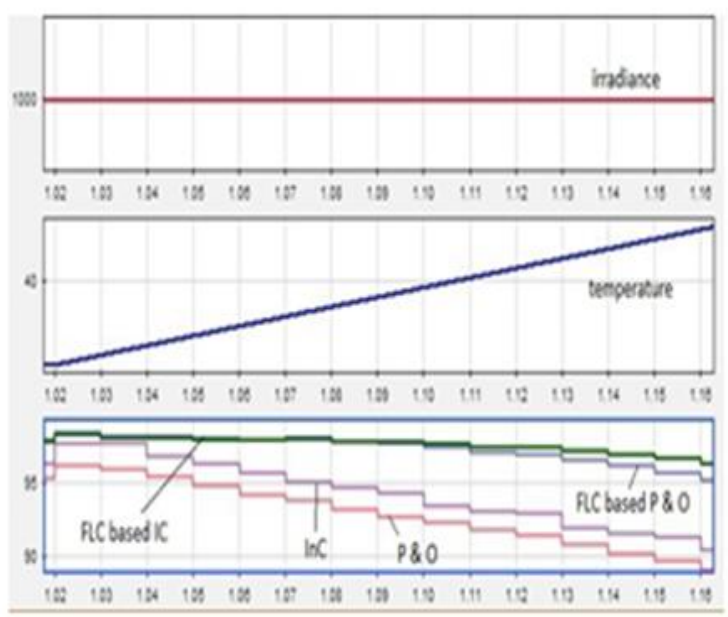

\section{Figure 12: Power Characteristics in stage 5}

Stage 6:

From (1.17 to 1.35) the temperature is maintained constant $50^{\circ}$ Celsius and the irradiance is $1000 \mathrm{w} / \mathrm{m} 2$. The variation of power is also constant due to variation of irradiance and temperature are constant.

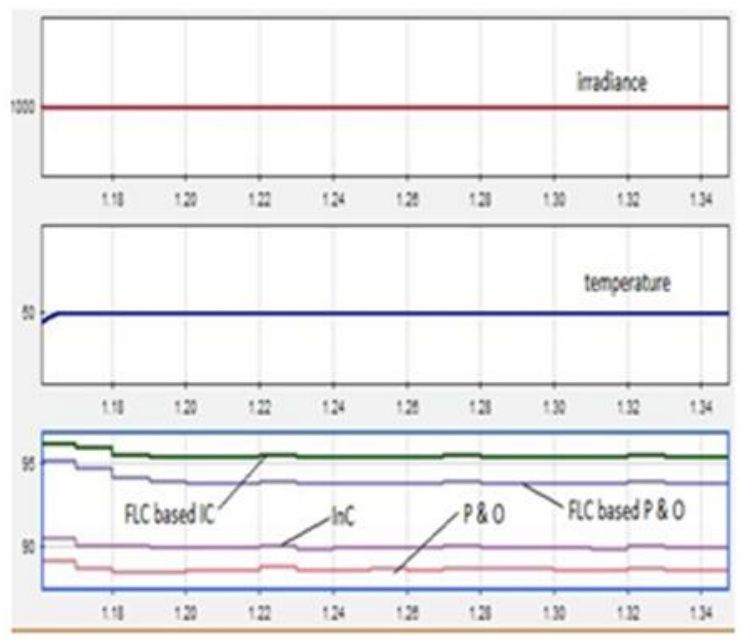

Figure 13: Power Characteristics in stage 6

Incremental method has more power when compared to $\mathrm{P}$ \& O but has less power when compared FLC based IC and FLC based P\&O methods.

\section{Stage 7:}

From (1.36 to 1.5 ) the temperature is decreasing from $50^{\circ} \mathrm{Celsius}$ to $25^{\circ} \mathrm{Celsius}$ and the irradiance is $1000 \mathrm{w} / \mathrm{m} 2$. The variation of power is increasing due to variation of temperature.

FLC based IC has more power when compared FLC based P \& O. P \& O method has less power when compared to other three methods. 


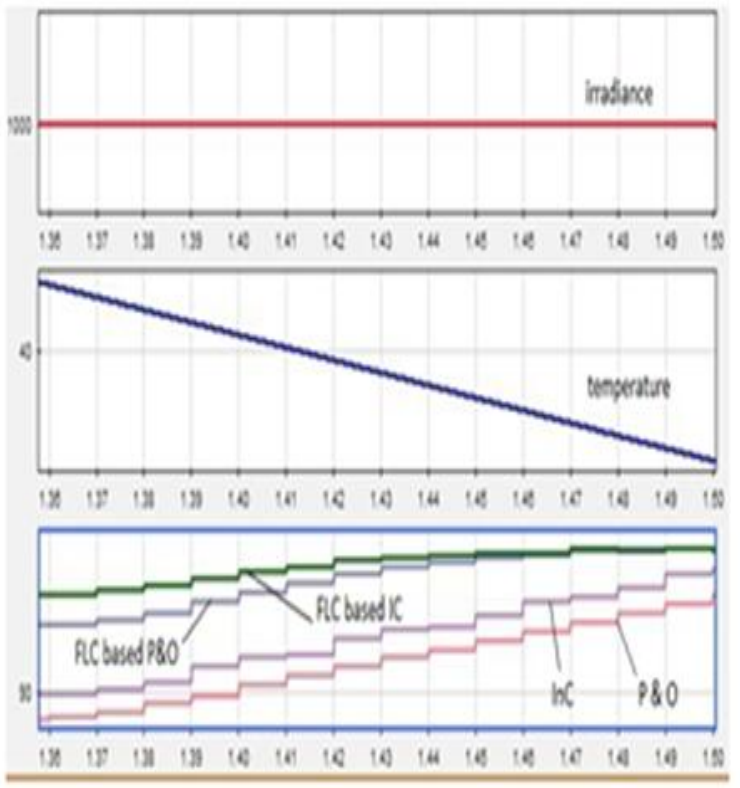

\section{Figure 14: Power Characteristics in stage 7}

\section{Stage 8:}

From (1.5 to 1.65$)$ the irradiation is decreases from $1000 \mathrm{w} / \mathrm{m} 2$ to $500 \mathrm{w} / \mathrm{m} 2$ and the temperature is increases from $25^{\circ}$ Celsius to $50^{\circ}$ Celsius. The variation of power is decreases due to effect of variation of both irradiance and temperature.

$\mathrm{P} \& \mathrm{O}$ method has less power when compared IC method. FLC based IC has more power compared to remaining methods.

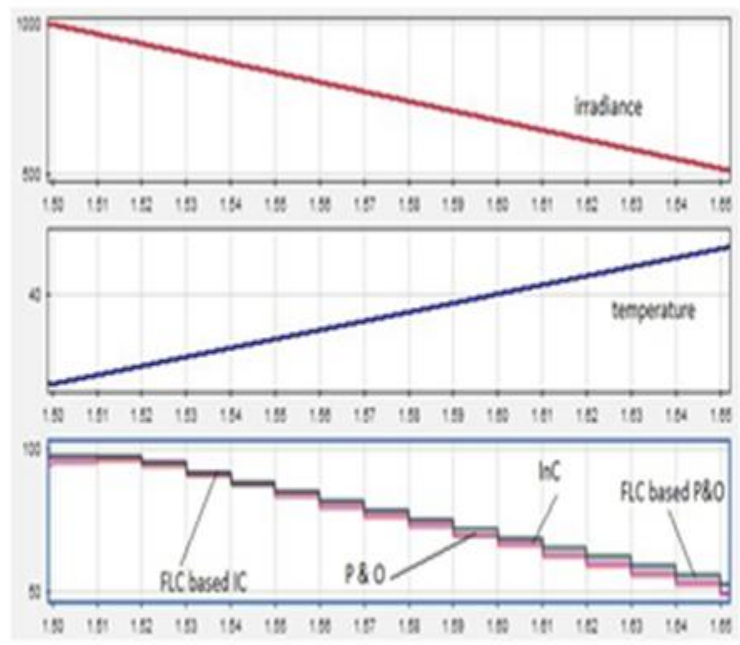

Figure 15: Power Characteristics in stage 8

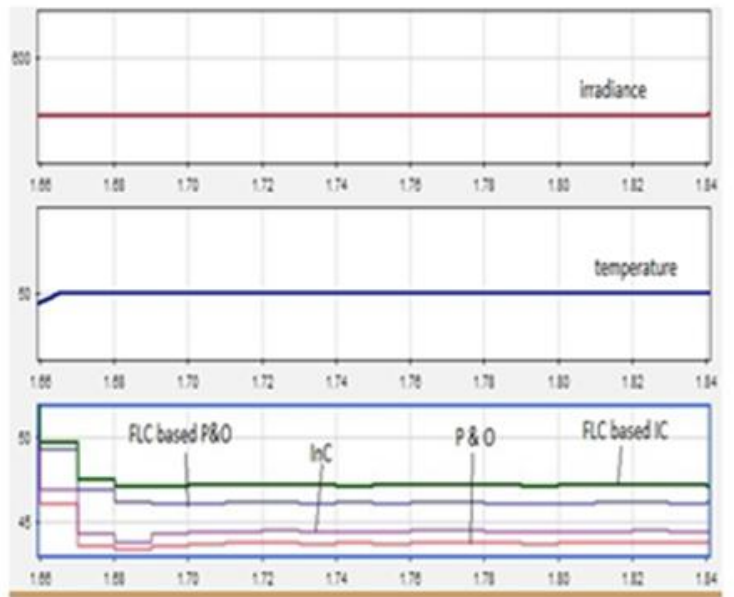

Figure 16: Power Characteristics in stage 9

Stage 9:

From (1.66 to 1.85 ) the irradiation is maintained constant $500 \mathrm{w} / \mathrm{m} 2$ and the temperature is also maintained constant at $50^{\circ}$ Celsius. The variation of power is constant due to effect of both irradiance and temperature maintained constant.

It shows that $\mathrm{P} \& \mathrm{O}$ method has less power when compared IC method. FLC based IC has more power.

\section{Stage 10:}

From (1.86 to 2 ) the irradiation is increases from $500 \mathrm{w} / \mathrm{m} 2$ to $1000 \mathrm{w} / \mathrm{m} 2$ and the temperature is decreasing from $50^{\circ} \mathrm{Celsius}$ to $25^{\circ} \mathrm{Celsius}$. The variation of power is increases due to the effect of variation of irradiance and temperature.

Incremental method has more power when compared to $\mathrm{P}$ $\&$ O but has less power when compared FLC based IC and FLC based P\&O methods.

Stage 11:

From (2 to 2.5 ) the irradiation is $1000 \mathrm{w} / \mathrm{m} 2$ and the temperature is $25^{\circ} \mathrm{Celsius}$. The variation of power is constant due to the

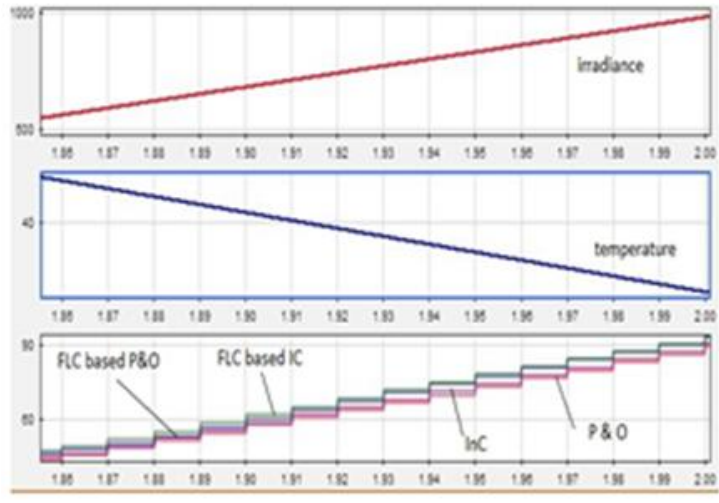

Figure 17: Power Characteristics in stage 10

effect of both irradiance and temperature are maintained constant.

FLC based IC has more power when compared FLC based $\mathrm{P} \& \mathrm{O}$. P \& O method has less power when compared to other four methods.

Published By:

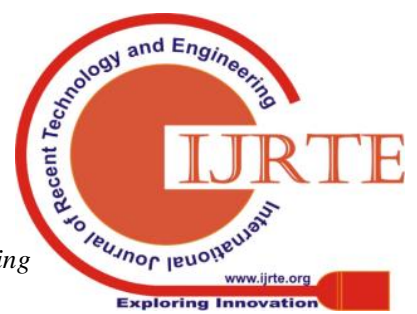




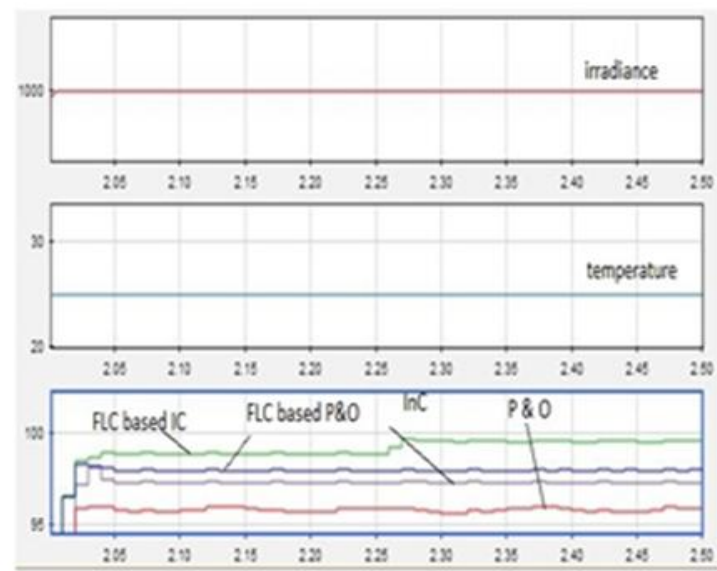

Figure 18: Power Characteristics in stage 11
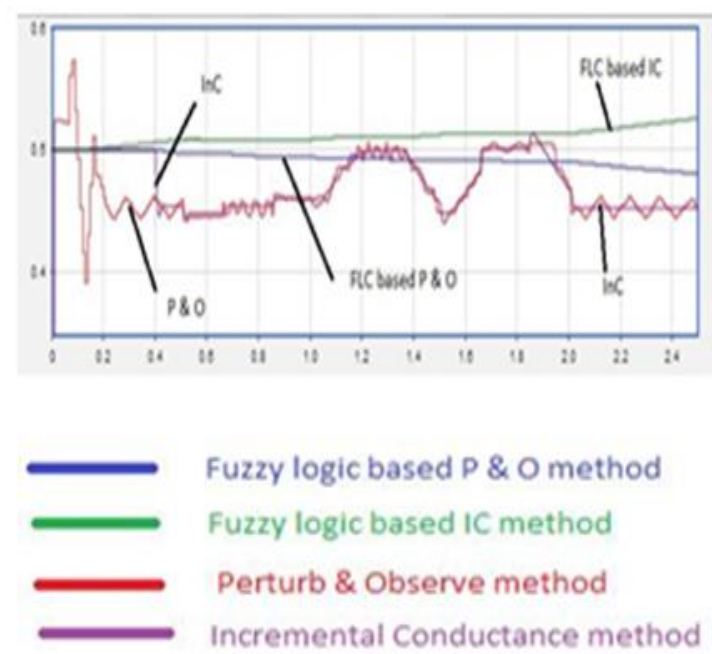

\section{Figure 19: Comparison of Duty Cycle of an grid Photo Voltaic system showing various MPPT alg orithms vs time}

\section{CONCLUSIONS}

In this paper different MPPT techniques are analyzed by varying the temperature and irradiation as different stages and simulation models for MPPT are presented. In some stages FLC based P\&O performed well in the extraction of Maximum power and in some stages FLC based IC method performed well. Butconsideringminimum Oscillations and maximum power obtained, FLC based IC is the best among the algorithms analyzed.

\section{REFERENCES}

1. Sumedha Sengar 'Maximum Power Point Tracking Algorithms for Photovoltaic System: A Review' International Review of Applied Engineering Research. ISSN 2248-9967 Volume 4, Number 2 (2014), pp. 147-154.

2. Raghuram Munasala, $T$ Padmavathi 'Analysis of Maximum Power Point Trackingtechniques for Photo Voltaic System'

3. Bhasuthkar Niharika, Sudarshan TSB,' Maximum Power Point Tracking Controller for Solar Powered mUAV' IEEE International Conference on Power, Control,
Signals and Instrumentation Engineering (ICPCSI-2017).

4. Nada Zinelaabidine, Mohammed Karim, Badre Bossoufi, Mohammed Taoussi'Mppt Algorithm Control For Grid Connected PV Module, 3rd International Conference on Advanced Technologies for Signal and Image Processing - ATSIP'2017,May 22-24, 2017, Fez, Morroco

5. Carlos Robles Algarín* ID , John Taborda Giraldo and Omar Rodríguez Álvarez Fuzzy Logic Based MPPT Controller for a PV System

6. Abdullah M. Noman, Khaled E. Addoweesh, Hussein M. Mashaly 'Fuzzy Logic Control Method for MPPT of PV Systems' 978-1-4673-2420-5/12/\$31.00 @2012 IEEE

7. Hasan Mahamudul, Mekhilef Saad, and Metselaar Ibrahim Henk 'Photovoltaic System Modeling with Fuzzy Logic Based Maximum Power Point Tracking Algorithm'Hindawi Publishing CorporationInternational Journal of Photoenergy Volume 2013, Article ID 762946.

8. Kashif Ishaque, Zainal Salam and George Lauss 'The performance of perturb and observe and incremental conductance maximum power point tracking method under dynamic weather conditions 'Applied, 2014, vol. 119, issue C, 228-236.

9. M.A.A.Mohd Zainuri, M.A.Mohd Radzi, Azura Che, N.Abdul Rahim 'Adaptive P\&O-Fuzzy Control MPPT for PV Boost Dc-Dc Converter'2012 IEEE international conference on Power and Energy(PECon),2-5 December,2012,Malaysia

10. Chandani Sharma, Anamika Jain,'Hybrid Fuzzy Mpp Tracking System for Single AndMultivariable Environment

11. Salas V, Olias E, Barrado A, Lazaro A. "Review of the maximum power point tracking algorithms for standalone photovoltaic systems". Solar Energy Materials \&Solar Cells2006; 90:1555-78.

12. Liu Xuejun. "An improved perturbation and observation maximum power point tracking algorithm for PV arrays", Power Electronics Specialists Conference, 2004. PESC 04. 2004 IEEE 35th Annual.

13. F. Liu, S. Duan, F. Liu, B. Liu, and Y. Kang, "A variable step size INC MPPT method for PV systems", Industrial Electronics, IEEE Transactions on, vol. 55, no 7, p. 2622-2628,2008.

14. S. Nema, R.K.Nema, and G.Agnihotri, "Matlab/Simulink based study of photovoltaic cells/modules/array and their experimental verification", International Journal of Energy and Environment, pp.487-500, Volume 1, Issue 3, 2010.

15. T. Ishii, M.Yoshida, M.Motomori, J Hara "Buckboost converter", US Patent 7,268,525, 2007.

16. MG Villalva, JR Gazoli, ER Filho, "Modeling and circuit-based simulation of photovoltaic arrays", Power Electronics Conference, 2009. COBEP '09. Brazilian.

17. J.L. Santos, F. Antunes, A. Chehab and C. Cruz, 'A Maximum Power Point Tracker for PV Systems Using a High Performance Boost Converter', Solar Energy, Vol. 80, N7, pp. $772-778,206$

18. B Subudhi, R Pradhan, 'A comparative study on maximum power point tracking techniques for photovoltaic power systems', IEEE Transactions on Sustainable Energy ( Volume: 4, Issue: 1, Jan. 2013).

19. Ali Chermitti, Omar Boukli-Hacene, Samir Mouhadjer, 'Design of a Library of Components for Autonomous Photovoltaic System under Matlab/Simulink', International Journal of Computer Applications (0975 8887), Volume 53- No.14, September 2012. 
20. I. V. Banu, R. Beniuga, and M. Istrate, 'Comparative analysis of the perturb-andobserve and incremental conductance MPPT methods', in Advanced Topics in Electrical Engineering (ATEE), 2013 8th International Symposium on, 2013, p. 1-4.

21. P Takun, S Kaitwanidvilai, C Jettanasen, 'Maximum Power Point Tracking using Fuzzy Logic Control for Photovoltaic Systems', International MultiConferance of Engineers and compute Scientists IMECS 2011, March 16 -18 , Hong Kong.

22. Muthubalaji, S., M. Abdul Kareem, N. Karuppiah, and M. G. Sugirtha. "An enhanced analysis of two diode model PV module under various weather conditions." In 2017 IEEE International Conference on Circuits and Systems (ICCS), pp. 162-167. IEEE, 2017. 